7. Reprod. Fert. (1967) 13, 375-376

BRIEF COMMUNICATION

\title{
A DIRECT MEASUREMENT OF THE SEX-RATIO IN MOUSE BLASTOCYSTS
}

\author{
ANNE D. VICKERS \\ Physiological Laboratory, University of Cambridge
}

(Received 21st December 1966)

\begin{abstract}
Summary. Ninety-eight mouse blastocysts were sexed by means of chromosome analysis. Forty-nine were males and forty-nine were females, a sex-ratio of $50 \%$. It is concluded that there is no reason to believe that the sex-ratio at conception in the mouse is not $50 \%$.
\end{abstract}

The primary sex-ratio of mammals (the proportion of males to females at conception) has never been measured, but has attracted interesi because of indirect evidence that there may be a predominance of males at this stage in cattle (Jewell, 1921), pigs (Parkes, 1925) and man (Szontagh, Jakobovits \& Méhes, 1961). Observations on blastocysts have shown an excess of males in golden hamsters (Sundell, 1962) but not in rabbits (Melander, 1962).

In this experiment, 2- to 3-month-old virgin female mice from an albino strain (PDE) were used. Superovulation was induced by injecting 3 i.u. of PMSG followed $40 \frac{1}{2}$ to $46 \mathrm{hr}$ later by 3 i.u. of HCG. The females were then left overnight with PDE males of proven fertility, aged 8 to 10 months, and were killed on the 3rd day after the appearance of the vaginal plug, when the blastocysts were lying free in the uterine cavity. Colchicine $(1 \mu \mathrm{g} / \mathrm{g})$ was injected 1 to $5 \frac{1}{2} \mathrm{hr}$ before death to halt dividing cells in the metaphase stage of mitosis. The blastocysts were flushed from the uterine horns with either Hanks' balanced salt solution or Medium 199 (Microbiological Associates, U.S.A.) containing 15\% inactivated foetal calf serum, $5 \%$ phosphate buffer $(\mathrm{pH} 7.2)$ and 100 i.u. $/ \mathrm{ml}$ penicillin. New corpora lutea in the ovaries were counted and the Fallopian tubes searched if necessary. Blastocysts were transferred to hypotonic $\mathrm{KCl}$ $(0.075 \mathrm{M})$ for 10 to $20 \mathrm{~min}$ in order to swell the cells and help spread the chromosomes (Hungerford, 1965); after this treatment they were fixed by Tarkowski's method (1966). Freshly made acetic alcohol (one part of glacial acetic acid, three parts of $98 \%$ ethanol) was dropped onto the eggs on a slide and then allowed to evaporate thus producing rapid permanent mounts. The slides were stained for $1 \mathrm{hr}$ in $2 \%$ lactic-acetic-orcein, rinsed in $75 \%$ acetic acid, dehydrated and mounted in DPX or neutral Canada balsam. Slides were examined with a phase contrast microscope, and metaphase plates with the diploid complement of chromosomes were studied $(2 n=40)$. Stich \& Hsu (1960) showed that adult mouse somatic tissues could be sexed by observation 
of metaphase chromosomes: the karyotype of the male contains three very small chromosomes, an autosome pair plus the $\mathrm{Y}$, whilst the female karyotype contains two very small chromosomes.

Sixteen females produced fertilized blastocysts (one female with unfertilized eggs was discarded). The total number of new corpora lutea was 321 of which 176 were in right ovaries and 145 in left ovaries. On the assumption that 321 eggs were ovulated, the percentage recoveries were as follows: $69 \cdot 5 \%$ normal blastocysts (223), 14\% degenerating eggs (45), leaving $16.5 \%$ of the eggs unaccounted for (53). Degenerating eggs contained one or more abnormally shaped nuclei and were presumably unfertilized. Most blastocysts contained between 32 and 64 cells. Out of 223 recovered blastocysts it was possible to sex ninety-eight; forty-nine were males and forty-nine were females, i.e. a sex-ratio of $50 \%$. The number of chromosomes per cell was counted accurately for 115 blastocysts and 111 were diploid. Of the remainder, one was haploid, one trisomic, one had an isochromosome and one had thirty-nine chromosomes plus a chromosomal fragment. The haploid appeared degenerate and probably would not have implanted but the three aneuploids seemed normal and might well have continued development.

This work is being continued and a fuller account will follow later; it is hoped to produce some information about the factors which affect sex-ratio and the incidence of chromosomal abnormalities.

I should like to thank Professor A. S. Parkes, Dr R. G. Edwards and Dr T. Vickers for helpful advice, and Mrs K. McNicol and Miss G. Jackson who provided able technical assistance. This work was carried out during the tenure of a Medical Research Council grant; working expenses were defrayed by a grant from the Ford Foundation to Professor A. S. Parkes.

\section{REFERENCES}

HUNGERFord, D. A. (1965) Leucocytes cultured from small inocula of whole blood and the preparation of metaphase chromosomes by treatment with hypotonic KCl. Stain Technol. 40, 333.

Jewell, F. M. (1921) Sex-ratios in foetal cattle. Biol. Bull. mar. biol. Lab., Woods Hole, 41, 259.

MELANDER, Y. (1962) Chromosomal behaviour during the origin of sex chromatin in the rabbit. Hereditas, 48, 645 .

PARkes, A. S. (1925) Studies on the sex-ratio and related phenomena (7). The foetal sex-ratio in the pig. F. agric. Sci., Camb. 15, 284.

Strch, H. F. \& Hsu, T. C. (1960) Cytological identification of male and female somatic cells in the mouse. Expl Cell Res. 20, 248.

Sundell, G. (1962) The sex-ratio before uterine implantation in the golden hamster. F. Embryol. exp. Morph. 10, 58.

Szontagh, F. E., Jakobovits, A. \& Méhes, Ch. (1961) Primary embryonal sex-ratio in normal pregnancies determined by the nuclear chromatin. Nature, Lond. 192, 476.

TARKowsKI, A. K. (1966) An air-drying method for chromosome preparations from mouse eggs. Cytogenetics, 5, 394. 